\title{
Celebrating Morris F. Collen (1913-2014)
}

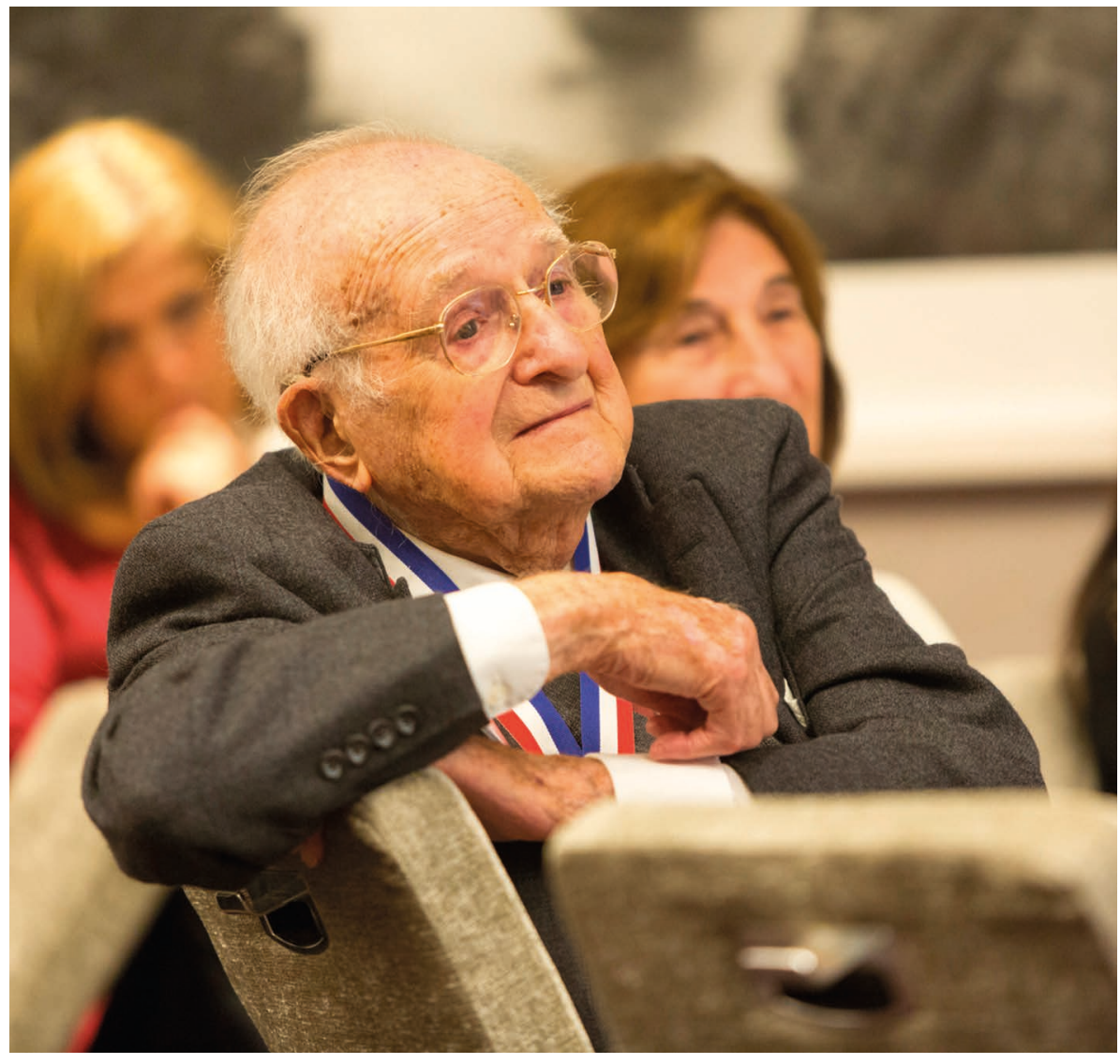

Fig. 1 Dr. Morris Collen listens to presentations at the symposium celebrating his 100th anniversary, San Francisco, 11/12/2013. Photo by Bill Horton, courtesy Kaiser Permanente Heritage Resources. physicians can now be board certified as a sub-specialist in Clinical Informatics.

The story of his life and work has been well told by Howard Bleich at the time of his $80^{\text {th }}$ birthday [1], by Jochen Moehr at the time of his $90^{\text {th }}$ birthday [2], and by Don Lindberg and Marion Ball as a tribute for his $100^{\text {th }}$ birthday [3].

Morris F. Collen, one of four children, was born in St. Paul, Minnesota on November 12,1913 . His father ran a grocery store and his mother was at home with the children. He credited his mother with giving him a birthdate that only a numerologist could love $11 / 12 / 13$. With a long-term interest in electrical gadgets, he enrolled in the University of Minnesota and obtained a degree in electrical engineering in 1935 . He had intended to obtain a $\mathrm{PhD}$ in the field but met a young nursing student who was to become his wife and she guided him to a career in medicine. He graduated from the University of Minnesota's School of Medicine "with distinction" in 1938 and headed to a warmer climate.

After finishing his residency in internal medicine at Los Angeles County hospital in 1942, he was recruited by Dr. Sidney Garfield to join a medical practice that staffed a new Permanente Foundation Hospital in Oakland,

How often does a person envision a new medical discipline, practice that discipline, mentor several generations of practitioners, help create the professional associations that promote this discipline and then live to see his or her vision come into reality? Morris F. Collen, who died September 17, 2014, just 6 weeks short of his $101^{\text {st }}$ birthday, was such a visionary, clinician, mentor, and gentle man. As a result of his pioneering efforts, information and communication technology used to improve health and healthcare is now commonplace in hospitals, clinician's offices, workplaces, schools and our homes. Today, physicians and nurses in the United States can train in informatics, and

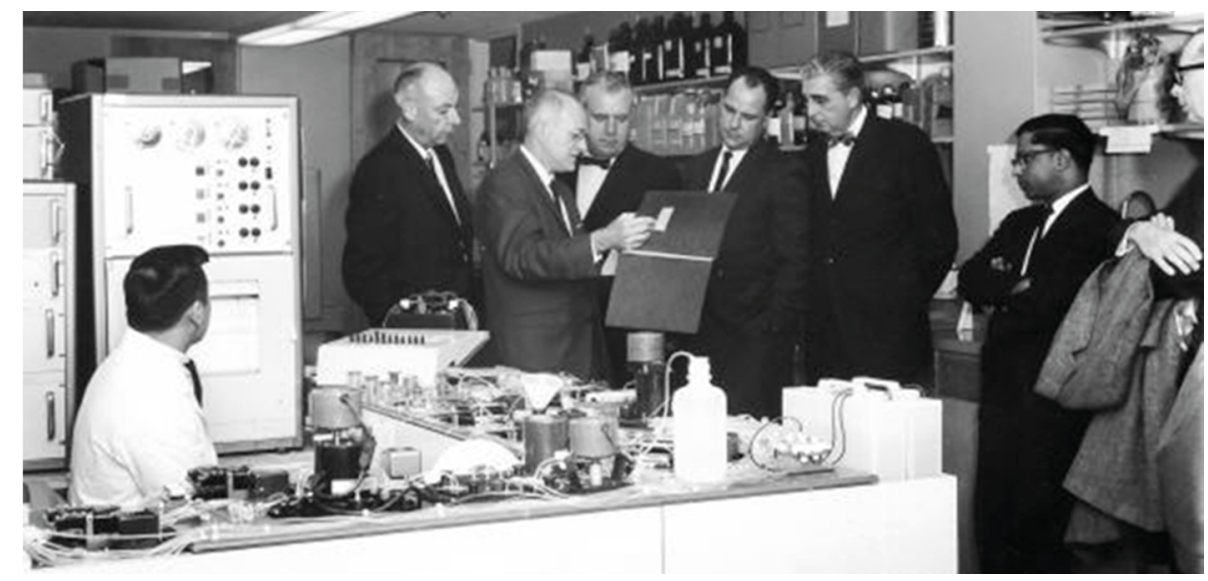

Fig. 2 Dr. Morris Collen explains to Public Health Service officials and congressmen how blood is analyzed by the equipment and results fed to computer, Kaiser Permanente, Oakland 2/1966. Photo courtesy Kaiser Permanente Heritage Resources. 
California, build by Henry Kaiser for his wartime shipyard workers. Dr. Collen, who had tried to enlist in the army but was turned down because of his asthma, was happy to join and support the war effort. He was a founding physician at the Kaiser Permanente health plan, an expert in occupational medicine for shipyard workers [4]. In one year, he treated more than 850 cases of pneumonia with such a low mortality rate he became a nationally recognized authority. Dr. Garfield promoted him to be "Chief of Medicine." Because of his reputation, he was able to obtain a limited supply of penicillin (most of which was being used overseas for soldiers) and became one of the first physicians to use penicillin in the treatment of Pneumococcal pneumonia [5].

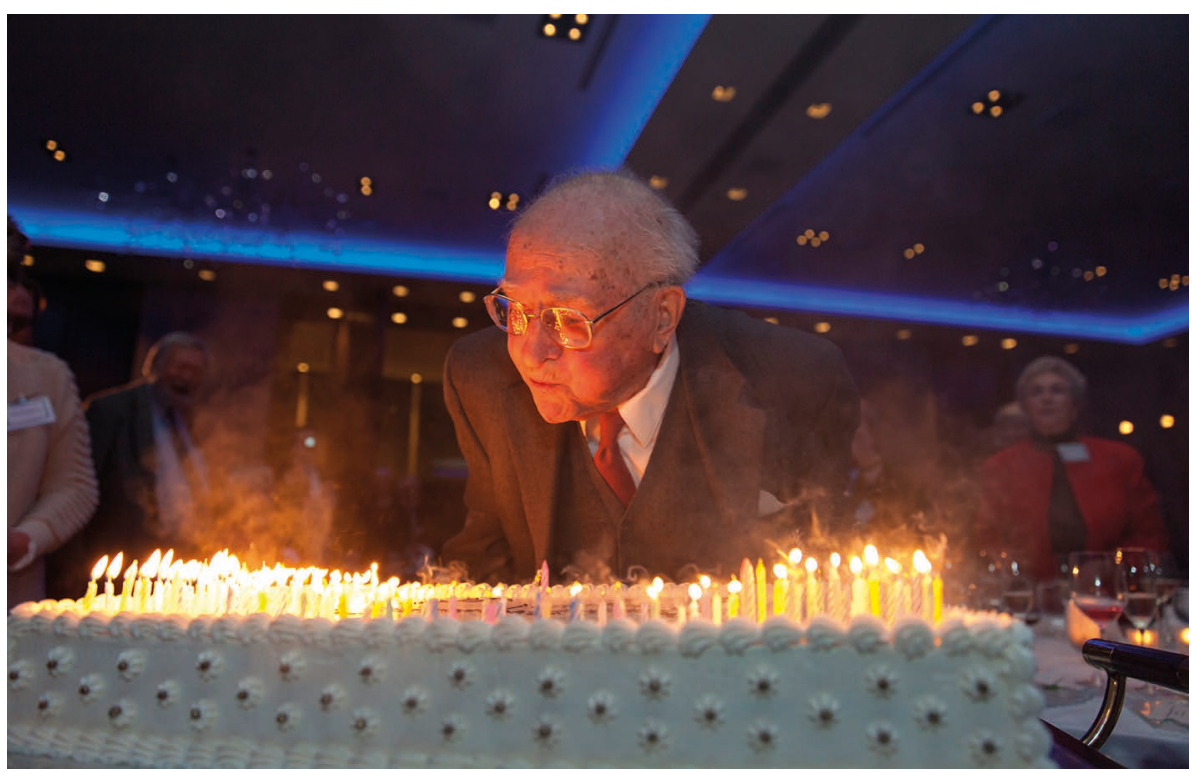

Fig. 3 Dr. Morris Collen still had enough breath to blow out all 100 candles at the symposium honoring his lifetime contribution to medical informatics, 11/12/2013. Photo by Bill Horton, courtesy Kaiser Permanente Heritage Resources.

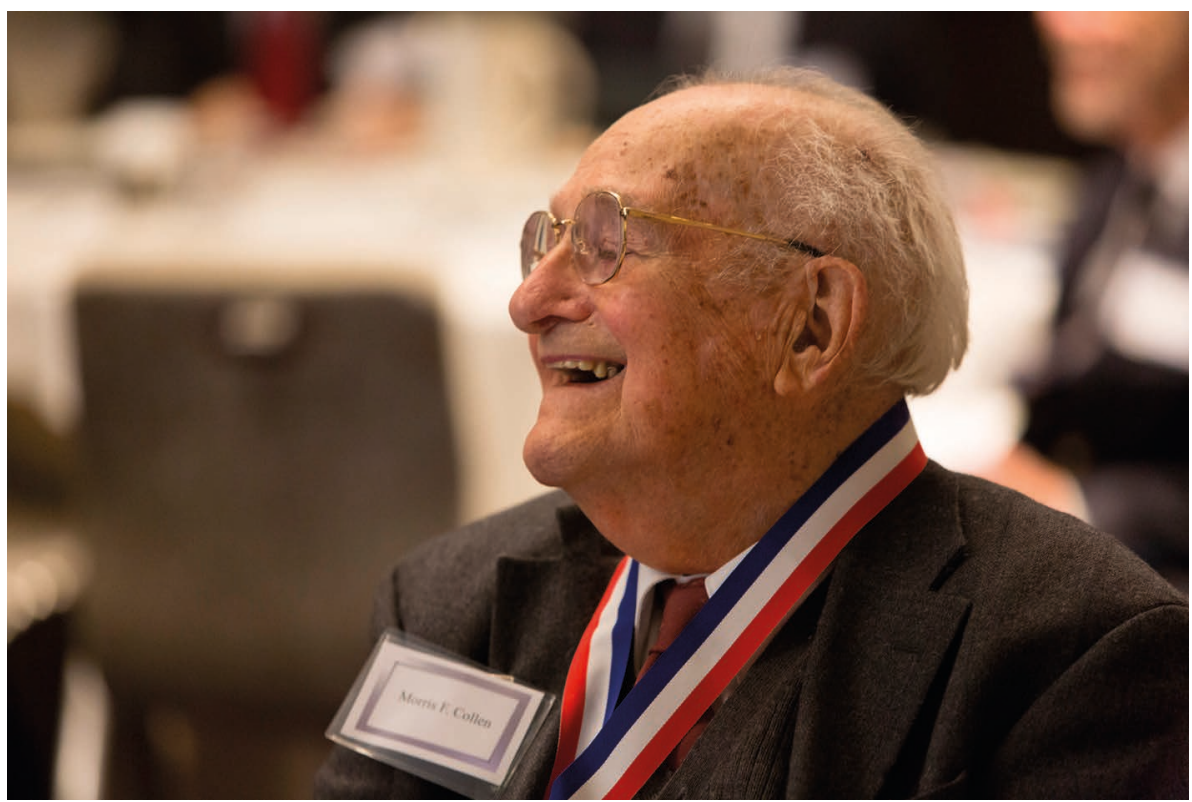

Fig. 4 Dr. Morris Collen, enjoying a lighter moment at the 100th, San Francisco, 11/12/2013. Photo by Bill Horton, courtesy Kaiser Permanente Heritage Resources.
As medical director of the Permanente Medical Group, Dr. Collen drew on his background in electrical engineering tno use automated equipment to increase the efficiency and quality of routine health screening. This involved not only interfacing medical devices, but also collecting information including a patient's history into a computer database. The results for each patient were then printed for the internist during a patient's visit. He called this systematic data collecting "multiphasic screening" and the database was arguably the world's first computer-based medical record [6]. He and his colleagues studied the data that resulted from their approach to health maintenance and observed a dramatic reduction in mortality from colon cancer and hypertension. This led to the development of practice guidelines. Really, he should be credited with beginning the field of evidence-based medicine. Ultimately Dr. Collen and his colleagues published over 150 articles relating to this work and he eventually founded and then directed the Kaiser Permanente Division of Research that today has an $\$ 82$ million research portfolio.

When Dr. Collen retired from active medical practice at age 70 , he was not only a living legend at Kaiser Permanente but also an international expert in the emerging area of Hospital Computer Systems [7]. However, I don't think "retirement" was in Dr. Collen's vocabulary. He remained active in research, mentoring and shaping the field of medical informatics. He helped create and nurture the very organizations that supported the professionals who identify as medical informaticians. He was a founder of the American College of Medical Informatics (ACMI), and a few years later he helped engineer the formation of the American Medical Informatics Association (AMIA) by merging the Symposium for Computer Applications in Medical Care (SCAMC), ACMI and AAMSI (American Association for Medical Systems and Informatics). He was integrally involved with the International Medical Informatics Association (IMIA) as well.

Many others knew Dr. Collen longer than I, but I had the privilege of knowing and being mentored by him during the last 


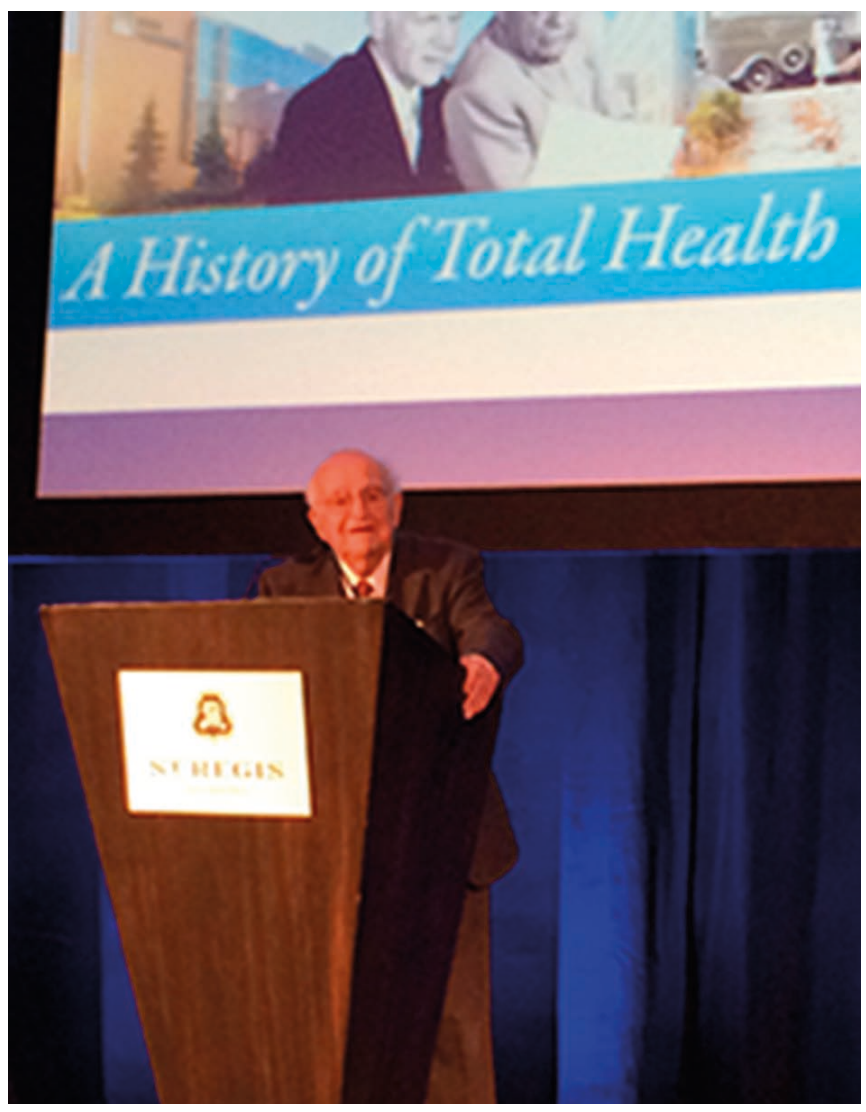

Fig. 5 Dr. Morris Collen gave a 20 min talk at 100th. The audience was enthralled. Photo by Bill Horton, courtesy Kaiser Permanente Heritage Resources.

two decades of his life. Although I knew who he was, I first really interacted with him during the 1993 Symposium for Computer Applications in Medical Care (now called the AMIA fall meeting). I was the scientific program chair, and the first Morris F. Collen award was being presented at that meeting. Of course, Dr. Collen was the first awardee and we all recognized that at least in the United States, he was "father of medical informatics."

I remember being in awe listening to a partial recount of these accomplishments when he received the first Collen Award. But what really impressed me over the next decade was his dedication and involvement in our field, both nationally and internationally. At nearly every meeting I attended, Dr. Collen was there. While others might be in the corridors talking, Dr. Collen was inside the session room listening to scientific presentations. After a session, he would go up to the speakers and ask questions and make suggestions on how to improve their talk. I know this because he approached me on more than one occasion to help.

Having lived through and participated in the seminal developments of early computerization of healthcare in the United States, Dr. Collen's labor of love during his retirement was a nearly 500 page comprehensive documentation of our field entitled "A History of Medical Informatics in the United States" published in 1995. His compendium and his life work demonstrate that many of today's innovations in health information technology have their roots in the prior work of others. His book, therefore, serves as a valuable reference. Over the past several years of his life, he worked daily on the second edition of "A History of Medical Informatics in the United States." He was truly worried that his second edition would not be completed before his death. On the occasion of his $100^{\text {th }}$ birthday, luminaries from the field of Medical Informatics (including most of the living Collen award winners) came to celebrate his life and the creation of a new medical subspe- cialty, "Clinical Informatics," that he inspired. Through his close friend, Dr. Marion Ball, these luminaries have stepped forward to enhance and complete his labor of love.

Two sons and a daughter survive Dr. Collen. His wife, Bobbie, who directed him into medicine and a son died before him.

Dr. Collen's legacy is profound. More than having lived a long and productive life, he touched lives. He was a pioneering physician; mentored my mentors; and with a gentle but firm hand guided and helped birth a new discipline. Speaking for the many students, clinicians, and patients whose lives are better because of Morris F. Collen, thank you.

\section{References}

1. Bleich HL. MD Computing 1994;11:136-9.

2. Moehr JR. To Morris F. Collen: Happy ninetieth! J Am Med Inform Assoc 2003;10:613-5.

3. Lindberg DAB, Ball MJ. Morris F. Collen at 100: A Tribute to "The Father of Medical Informatics." Methods Inf Med 2013;52:371-3.).

4. Collen MF, Dybdahl GL, O'Brien GF. A Study of Pneumonia in the Shipbuilding Industry. J Indust Hyg and Toxic 1944;26:1

5. Collen MF, Sellers AL. Penicillin Therapy of Pneumococcic Pneumonia. Permanente Foundation Med Bull 1945;3:49.

6. Collen MF, Rubin L, Neyman J, Dantzig G, Baer R, Siegelaub A. Automated Multiphasic Screening and Diagnosis. Am J Public Health 1964;54:741.

7. Collen MF, editor. Hospital Computer Systems. New York: John Wiley \& Sons; 1974.

By Charles Safran, MD

Associate Professor of Medicine

Harvard Medical School

2014 recipient of the Morris F. Collen Award 